\title{
Agrocraft as a Creative Economy Development: Woven Bamboo
}

\author{
Winda Amilia \\ Department of Agroindustrial Technology, Faculty of Agricultural Technology \\ University of Jember, Jl. Kalimantan 37 Jember 68100, Indonesia. \\ Email: windaprasetya@gmail.com
}

\begin{abstract}
Developed countries are realized that the economic growth not only depend on the industrial sector. The Goverment of Indonesia launched the creative economy development program on 2009 to develop creative economy which driven by the industrial sector called the creative industries. The creative industries is driven by creativity and innovation. Calok is a village in Jember regency which have the potential creative industry based on woven bamboo and agriculture. It creates a new sector of creative industries named agrocraft industry. The purpose of this research is developing the best business strategy by adopting the local wisdom of Calok using Strength Weaknesses Opportunities Threaths (SWOT) analysis. The Eksternal Factor Evaluation (EFE) and Internal Factor Evaluation (IFE) analysis shown that EFE matrix has a total score of 3.065 while IFE matrix has a total score of 2.302. By this result, the position of Calok community enterprise is in quadrant II. Analysing Qualitative Strategy Planning Method shown the alternative strategy should be applied is product development. The developed business strategy are new product design, spesialization product line, improvement design skills, designing product with less technology need.
\end{abstract}

\section{Keywords: agrocraft industry, strategy development, SWOT analysis, woven bamboo}

\section{INTRODUCTION}

Small Medium Enterprises (SMEs) play a key role of economics growth on developing countries. In Indonesia, SMEs have historically been the main player in domestic economic activities, especially as a large provider of employment opportunities, and hence a generator of primary or secondary sources of income for many households (Tambunan, 2008). SMEs are the generators of employment and job creation. SMEs also as a drivers of innovation. SMEs face the challenges of globalization and liberalization, for some SMEs this challenges are the barrier to develop their enterprises (OECD, 2004).

Calok is a village in Jember regency, its about $250 \mathrm{~km}$ from Bali and $199 \mathrm{~km}$ from Surabaya. Bamboo is one of their agricultural product and it open an opportunities to handicraft industry. Calok also have a lot potential sgricultural product, and it have a chance to be developed as a new sector of creative industry named agrocraft. Handicraft is a part of creative industries, it related to the creation, production, and distribution of products made by qualified craftsmen produce handicrafts made of: precious stones, natural or artificial fibers, leather, rattan, bamboo, wood, metal (gold, silver, copper, bronze, iron), wood, glass, porcelain, cloth, marble, clay, and limestone (Dalimunthe and Faritzal, 2011).

As agrocraft product, woven bamboo should be improve continously of innovation and creativity. Creativity is starting point for innovation (Okpara, 2007). The creative and cultural industries are generally considered one of the key sectors and an engine driving of new products innovation. Innovation is the primary key to gain sustainable growth. Innovation important as a driver of 
competitiveness, profitability, and productivity in small to medium sized enterprises (SMEs). Innovation is defined by Linder et al. (in Farsi and Toghraae, 2014) as implementing new ideas that create value. Innovation means the adoption of new products and/or processes to increase competitiveness and to meet the customers' requirements. Innovation also a tool of the entrepreneurship (Drucker, 1985).

The woven bamboo craftmen group on Calok build an community enterprise based on their culture, local wisdom, and potential economic named Komplit. Komplit as the SMEs facing many problem during their development. Lack of information, lack of marketing channel, low entrepreneurship skill, less educated people, and their traditional mindset of handicraft job are the barrier to improve. For years, this community enterprise made a household items traditional product of woven bamboo which it minimum profit margin and made they as a poor. But as the modern market study shows, a new market is emerging for handmade utilitarian and decorative objects.

A lot of potential resources on Calok is needed to be develop. They have to change the problem and weaknesses into the opportunities to growth. This community enterprise have to improve their business strategy to gain the modern market opportunities. The objectives of this study is develop business for Komplit as a community enterprise. It is necessary to develop this community enterprise business strategy to help improve their business and welfare. This study using SWOT to identification the strengths, weaknessess, oppportunities, and threaths variables to develop the community enterprise.

\section{METHODS}

This study using qualitative method. The methodology is given in flow chart (figure 1). It starts from SWOT variables identification, data collection from all the member of community enterprise (33 people), followed by Eksternal Factor Evaluation (EFE) and Internal Factor Evaluation (IFE) analysis, Formating the SWOT matrix and Internal Eksternal Matrix, and at the end is developing strategy planning based on the SWOT analysis.

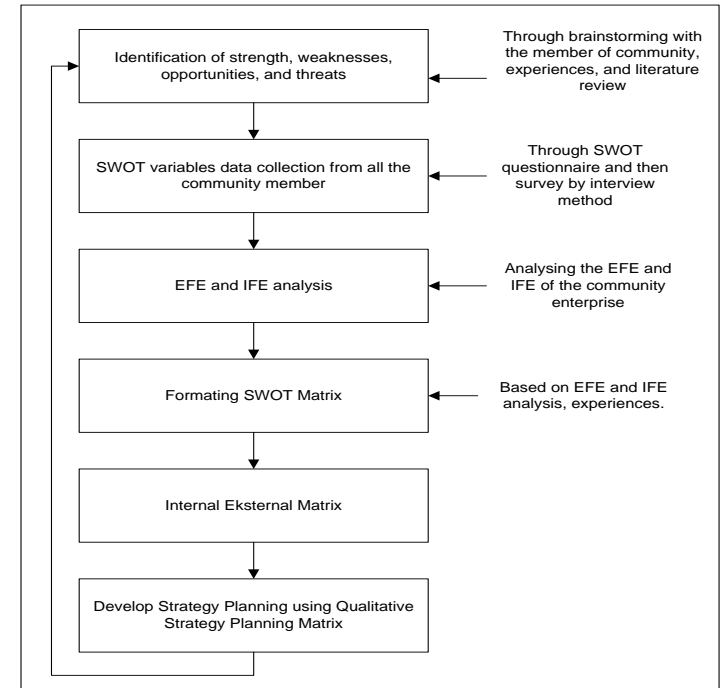

Figure 1. Methodology Flowchart

The community enterprise (Komplit) member is 33 people, they are the respondence of the survey. The thirty two SWOT variables are identified based on the prior experience of the researcher and the craftmen with the help of brainstorming method. The thirty two variables are evaluated using SPSS 17.0 to analyse the validity and reliability, and the result shows that only twenty nine variables are reliable. All the twenty nine questionnaires are surveyed by interview through all the community member. They are asked to rate the variables on Likert 5 point scale (1-extremely unimportant, 2-slightly unimportant, 3-neither unimportant or important, 4-slightly important, 5-extremely important).

The Qualitative Strategy Planning Methods process development as the follow:

a. Put the eksternal and internal success factor on the left side of the matrix.

b. Put the weight of eksternal and internal variables

c. Set the Attractiveness Score (AS) that indicates the attractiveness relative to each of the chosen strategy (1-not attractive, 2-slightly attractive, 3rasionally attractive, 4-very attractive).

d. Calculate the Total Attractiveness Score (TAS) by multiplying weight and AS on each line.

e. Calculate the sum of TAS vertically.

The highest result show that it is the best strategy to develop. 


\section{RESULTS}

The community enterprise environment is identified using EFE and IFE analysis. The community enterprises eksternal and internal factor in needed to build a matrix strategy on SWOT analysis. The IFE matrix shows 3.065 point of eksternal success factor. The EFE matrix shows 2.32 point of internal success factor. This result shows that this woven bamboo community enterprise have a chance to growth.
SWOT matrix is using tho shows the community enterprise strategic factor. This matrix will describe clearly how external factor facing tje company internal factor. This matrix used to develop four types of strategies, namely SO (strengthsopportunities) strategies, WO (weaknesses-opportunities) strategy, ST (strengths-threaths) strategy, and WT (weaknesses-threaths) strategy. This SWOT matrix as shown on table 1 .

Table 1. Strengths Weaknesses Opportunities Threaths Matrix

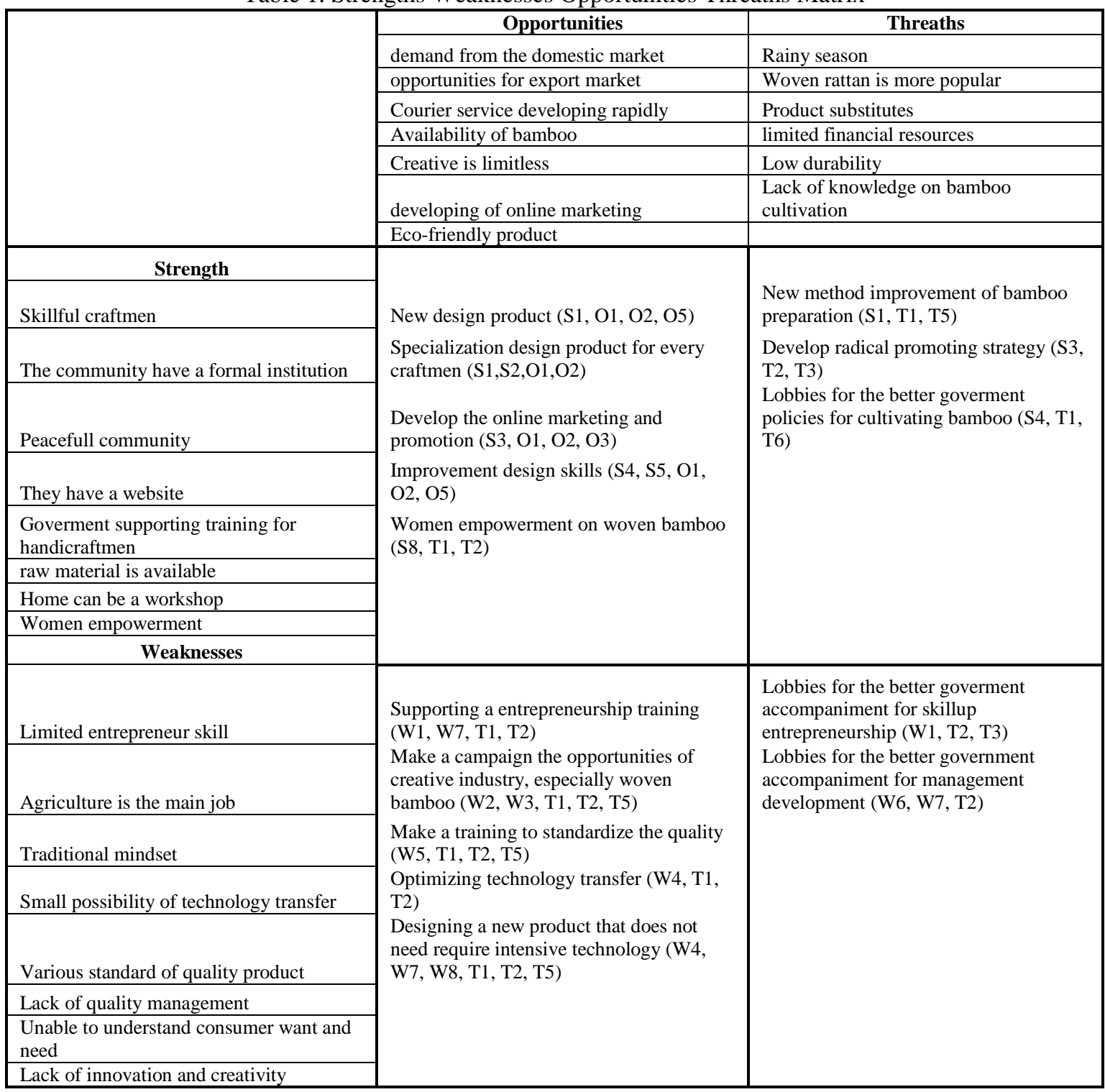

The strategy development process after the SWOT analysis is building IE (internal eksternal) matrix. This matrix will show the community enterprise position on the business competition. Based on this IFE and EFE skor, the community enterprise (Calok) is 
in quadrant II. It means that this community enterprise (Komplit) have three alternative strategy option to be develop: product development, management development, or market development.
The strategy planning using QSPM is using to choose the best alternative strategy to be adopted. This QSPM matrix show that the best strategy is product development (table 2).

Table 2. Qualitative Strategy Planning Matrix

\begin{tabular}{|c|c|c|c|c|c|c|c|}
\hline \multirow{3}{*}{ Key Factors } & \multicolumn{3}{|c|}{ Alternative 1} & \multicolumn{2}{|c|}{ Alternative 2} & \multicolumn{2}{|c|}{ Alternatif 3} \\
\hline & \multicolumn{3}{|c|}{ Product Development } & \multicolumn{2}{|c|}{ Management Dev. } & \multicolumn{2}{|c|}{ Market Dev. } \\
\hline & Weight & AS & TAS & AS & TAS & AS & TAS \\
\hline \multicolumn{8}{|l|}{ Strength } \\
\hline skillful craftmen & 0.08 & 4 & 0.32 & 2 & 0.16 & 4 & 0.32 \\
\hline The community have a formal institution & 0.04 & 1 & 0.04 & 4 & 0.16 & 2 & 0.08 \\
\hline Peacefull community & 0.06 & 1 & 0.06 & 4 & 0.24 & 1 & 0.06 \\
\hline They have a website & 0.06 & 2 & 0.12 & 2 & 0.12 & 4 & 0.24 \\
\hline Goverment supporting training for craftmen & 0.06 & 2 & 0.12 & 4 & 0.24 & 2 & 0.12 \\
\hline raw material is available & 0.08 & 3 & 0.24 & 1 & 0.08 & 1 & 0.08 \\
\hline Home can be a workshop & 0.04 & 2 & 0.08 & 1 & 0.04 & 1 & 0.04 \\
\hline Women empowerment & 0.06 & 3 & 0.18 & 3 & 0.18 & 1 & 0.06 \\
\hline \multicolumn{8}{|l|}{ Weaknesses } \\
\hline Limited entrepreneur skill & 0.08 & 1 & 0.08 & 3 & 0.24 & 3 & 0.08 \\
\hline Agriculture is the main job & 0.04 & 1 & 0.04 & 3 & 0.12 & 1 & 0.04 \\
\hline Traditional mindset & 0.06 & 2 & 0.12 & 3 & 0.18 & 1 & 0.06 \\
\hline Small possibility of technology transfer & 0.06 & 3 & 0.18 & 2 & 0.12 & 1 & 0.06 \\
\hline Various standard of quality product & 0.08 & 3 & 0.24 & & & 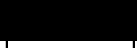 & . \\
\hline Lack of quality management & 0.06 & 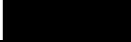 & & 4 & 0.24 & 2 & 0.18 \\
\hline Unable to understand consumer want and need & 0.08 & 3 & 0.24 & & & 3 & 0.24 \\
\hline Lack of innovation and creativity & 0.06 & 3 & 0.18 & & & 3 & 0.18 \\
\hline \multicolumn{8}{|l|}{ SUM WEIGHTS } \\
\hline \multicolumn{8}{|l|}{ Opportunities } \\
\hline demand from the domestic market & 0.085 & 4 & 0.34 & 2 & 0.17 & 4 & 0.34 \\
\hline opportunities for export market & 0.085 & 4 & 0.34 & 2 & 0.17 & 4 & 0.255 \\
\hline Courier service developing rapidly & 0.095 & 3 & 0.285 & 1 & 0.095 & 3 & 0.285 \\
\hline Availability of bamboo & 0.07 & 3 & 0.21 & & & 3 & 0.21 \\
\hline Creative is limitless & 0.07 & 4 & 0.28 & & & 3 & 0.21 \\
\hline developing of online marketing & 0.095 & 4 & 0.38 & & & 3 & 0.38 \\
\hline Eco-friendly product & 0.07 & 4 & 0.28 & & & 4 & 0.28 \\
\hline \multicolumn{8}{|l|}{ Threaths } \\
\hline Rainy season & 0.07 & 4 & 0.28 & & & & \\
\hline Woven rattan is more popular & 0.095 & 4 & 0.38 & & & 3 & 0.285 \\
\hline Product substitutes & 0.095 & 3 & 0.285 & & & 3 & 0.285 \\
\hline limited financial resources & 0.07 & & & 3 & 0.21 & & \\
\hline Low durability & 0.05 & 3 & 0.15 & & & & \\
\hline Lack of knowledge on bamboo cultivation & 0.05 & 2 & 0.1 & & & & \\
\hline \multicolumn{8}{|l|}{ SUM WEIGHTS } \\
\hline SUMTAS & & & 5.55 & & 2.765 & & 4.37 \\
\hline
\end{tabular}




\section{DISCUSSION}

Geographically, near Bali is a good opportunities for creative industry in Jember. This opportunity should be develop into a high quality product and the right business strategies. This community enterprise Komplit) need the right strategy to develop their woven bamboo business.

The IFE result shown better number than the EFE. It shows that this community enterprise have a good chance to growth. Based on the IE matrix, quadrant II is offer three development strategy options: product development, management development, or marekt development. By the QSPM matrix, show that the best strategy to develop is product development.

Product development is necessary to do because the high profit margin is offering by the modern market. As the strategy describe on SWOT matrix, the business strategy should be develop are:

4.1 New product design

In the modern market, they do not need a household items from bamboo. But they want a bamboo product for the decorative or furniture product. This modern market offering higher profit margin than the traditional market.

4.2 Specialization product line

Specialization product for every craftsmen is needed to improve skills the craftmen and improve the quality. The craftmen divided into several group, which every group hava one line production. The group could be: interior decorative, modern furniture, multipurpose product.

4.3 Improvement design skills

Their design skills should be updated continuously to follow the costumer requirement.

4.4 Designing product with less technology need

In the handihandicraft market, study show that the more handmade the more price to get. The costumer will pay more for the better design skill (Adhikary, 2015). This is a opportunity for the handicraftmen in Calok to make a skillfull product.

During this study, the craftmen tried to make a new design product for the decorative. This product is offering for the modern ethnic home concept and for decorative in bank office. The costumer response were unpredictable. This new product design is giving $70 \%$ profit margin than the household product which only gain $20 \%$ profit margin. Its also higher than their salary work on agriculture sector.

Those condition shows that handicraft is very special product, where the market could be involved by the trends, the craftman skill required, the creativity, the innovation, and the design. Handicraft is an unique expression of a particular community and the culture through local handicraftmanship and material (Khan and Amir, 2012).

\section{CONCLUSION}

Using the strength and the opportunities, the community enterprise develop the business strategy to change the problem into the profit margin. The SWOT describe some strategy could be applied in this community enterprise. The QSPM chosen that product development should be the priority alternative. The business strategy for product development are new product design, specialization product line, improvement design skills, designing product with less technology need. The new product design strategy shows good result with $70 \%$ profit margin. It shows that the more effort on design innovation and creativity the more profit can get. The clearly finding is handicraft is a special product, where the price calculate from the skill required, the creativity, and the innovation.

\section{REFERENCES}

Adhikary, N. 2015. Economic Potential of Bamboo for The Traditional Bamboo Users in The Modern Economy. http://www.abari.org/economicpotential-of-bamboo-in-nepal/. [September 22, 2015].

Dalimunthe,G.P. and Faritzal,A. 2011. Identifying Post-Industrial Creative Entrepreneurship Competencies Bandung, Indonesia. Conference Paper of The 3rd Indonesia International conference On Innovation, Entrepreneurship, \& Small Business. July 26-28. Bandung: Indonesia. https://www.researchgate.net /publication/280007125_Identifying_Po 
st-

Industrial Creative Enterpreneurship C ompetencies_Bandung_Indonesia. [October 1, 2015].

Donovan, J., Stoian, D. and Poole, N. D. (2008). Global Review of Rural Enterprises: The long and winding road to creating viable businesses and potential shortcuts. Turrialba: Costa Rica.

Drucker, P.F. 1985. Innovation and Entrepreneurship. London: William Heinmann.

Dyahrini, W and Hasanah, A. 2008. Growing Creative Industry, a SWOT Analysis of Entrepreneurship of a Distribution Outlet at Bandung West Java. http://repository.widyatama.ac.id/x mlui/bitstream/handle/123456789/1335/ content.pdf?sequence $=1$. [October 2, 2015]

Farsi, J.Y. and Toghraae, M.T. 2014. Identification The Main Challenges of Small and Medium Sized Enterprises in Exploiting of Innovative Opportunities (Case Study: Iran SMEs). Journal of Global Entrepreneurship Research. Vol.
4:4.

http://www.journaljger.com/content/pdf/2251-7316-24.pdf. [September 20, 2015].

Khan, W.A. and Amir, Z. Study of Handicrat Marketing Strategies of Artisans in Uttar Pradesh and Its Implications. Research Journal of Management Sciences. Vol 2(2): 23-26. ISSN 23191171.

http://www.isca.in/IJMS/Archive/v2i2/5 .ISCA-RJMS-2012-057.pdf. [October 2, 2015].

OECD. 2014. Tourism and The Creative Economy. OECD Studies on Tourism. OECD Publishing. ISSN: 22239804. http://dx.doi.org/10.1787/9789264 207875-en. [September 20, 2015].

Okpara, F.O. 2007. The Value of Creativity and Innovation in Entrepreneurship. Journal of Asia Entrepreneurship and Sustainability. Vol.3:2.

Tambunan, T. 2008. SMEs Development in Indonesia: Do Economic Growth and Government Support Matter? International Journal of Asia Pasific Studies,.Vol. 4:2. 